\title{
Learning to Practice the Scientific Outlook on Development, Create New style Non-Government College of Civil Engineering Class
}

\author{
Yuan-Qin ZHAO \\ Changchun Architecture \& Civil Institute, ChangChun, JiLin, China (130607) \\ 1713823774@qq.com
}

\begin{abstract}
Keywords: Non-government College of Civil Engineering Class, The Scientific Outlook on Development, Style of Application Technology, Practice Teaching Base Group.
\end{abstract}

\begin{abstract}
Being led by implementing the scientific development concept with three basic concepts of "the development of innovative", "people-oriented" and "coordinated", giving full play to "two major advantages" of new non-government college itself and making great efforts to develop "three growth points", the necessity, practice and effect of creating new private college of civil Engineering class are illustrated on combination of theoretic and practice in this paper.
\end{abstract}

\section{Learning to Practice the Scientific Outlook on Development, Set up New Non-government College as the Primary Goal of Development}

Under the background of knowledge economy, the main characteristic of the new non-government college is: On the educational philosophy, more emphasis on the training objectives of school for "application technology style talents" and the core managerial ability that take the practice teaching base group, double type teachers a the system of optimization of the teaching model; In personnel training, take application technology as focal point, pay attention to cultivate students' project practice ability and innovation ability; In college management, pay more attention to the method of innovation, system innovation and system innovation; On the campus construction, Much more flowers, encourage education innovation and platform construction (such as college teaching management network and multi-function simulation system) .

Today, science and technology is development rapid, the total of human knowledge has increased dramatically, the world is competing in the field of economy, politics, military, education vigorously. Therefore, encouraging the students' learning motivation, cultivate students' practice ability and innovation ability, is important task for leaders at all levels and all the teachers and students staff of the non-government colleges. The talents that non-government college training, In between the theoretical research and practical operation personnel, he can be said for the personnel on production line of engineering and technical. The talents that non-government college training, "than ordinary undergraduates, they have a strong ability of engineering practice and the ability of application technology; than the higher vocational students, they have a system of discipline basic theory, have certain ability to creation and innovation of technology ${ }^{[1]}$. The Ministry of education "on further strengthening the several opinions of job of undergraduate course teaching of institutions of higher learning" demand: "Colleges and universities to strengthen the practice education consciousness, the difference between different disciplines to the requirement of practical teaching, reasonable practice teaching plan formulation, perfect the practice teaching system". To enhance the level of college practical teaching, one of the most serious problems at the beginning of the school we think about is how to adhere to the requirement of the Ministry of education, take the training goal for application technology style talents into our college education reality. To copy way people did before, not only can not overcome the disadvantages that lack the experiment practice and away from the construction suit also can't overcome "one-way in the teaching relationship" and the old way of teaching that "with teachers as the center, to the classroom as the center, the textbook as the center". The only effective way is to take the path of scientific development, create college practice teaching base group, that have all-round and multi-purpose. On the basis, optimize the mode of cultivating talents of application technology system to train application technology talents, 
to reconstruct the talent training scheme, enhance the level of running school based on a solid and effective.

Create the new private university, mainly based on three points to consider: This goal conforms to the overall deployment of the national development strategy. This goal conforms to the overall deployment of the national development strategy. This is a strategic decision for the realization of the great rejuvenation of the Chinese nation. First, university is an important part of the state, Is a place to train talents for national development. It has the important strategic position of priority development, plays a fundamental, overall and leading role in the construction and development of the country. Second this goal to meet the urgent needs of the global economic integration. With the rapid development of science and technology, competition of world economy, politics, military, education and many other aspects of the increasingly fierce, strategy and style of teaching has epoch-making change. If we want to win in the international competition in the initiative, then must actively promoting the education reform with Chinese characteristics. It requirement university must take the new talent cultivation for the twenty-first Century as the first priority development. Third, this goal adapt to the development trend of educational reform of colleges and Universities. After experienced Inheritance education marked by detailed professional and application technical education marked by professional deep fusion[2]. This is the modern education especially the mainstream trend and the essential characteristic of higher education. Therefore men must broaden their horizons, establish the innovative concept of development, to identify the positioning target of non-government college development, to grasp the new era university education trends and patterns. Thus founding the new private university is the inevitable choice of private school.

The idea is the guide of action. Changchun Institute of architecture was founded in 2000. From the beginning, the College had give full play to the advantages of two aspects of school parent and investment. That is the advantages of educational resources (The teachers of the school mother body, experience in running a school etc.) and the advantage of industry (Investment enterprise's engineering and technical personnel, the construction technology, money etc.). We are working on to construct the incubator for application technology style talents - practice teaching base group.

1.1 Built a nearly 5000 square meters of laboratory building, equipped with 20 available basic course experiment and experiment teaching laboratory

1.2 Built a more than 7000 square meters of hands-on workshop with six layer space "the Bauhaus". The workshop equipment advanced, complete function, for more than 10 professional students used in practice teaching. The hands-on workshop is divided into 6 with different functions and roles of practice teaching area, conversion the professional knowledge into a complete set of building design and construction production system reasonably. In the six layers are connected with each other in teaching space, show in front of "field teaching" teachers and students systematically.

1.3 The use of school building design institute existing conditions, equipment and human resources, equipment and human resources, to build a variety of functions "student design" , provides a basic platform to practice real professional for students,

1.4 Built a more than 6000 square meters of students practice innovation center. The center free of charge to the students and social enterprises to provide more than 30 rooms, take "to nest for keep the phoenix " form, the introduction of 8 related to building design, construction, inspection, engineering management and innovation of science and technology of Enterprise Inc.

1.5 Relying on the internal base group and school enterprise, build a "digital multimedia design practice teaching base", carry out and complete the project research work of "Civil engineering professional practice of digital simulation platform", as an important complement to the practice teaching.

\section{Establish New Concept of Talents, Take on the Cultivation of Application Technology Talents as the Primary Task for Private University Development}

On the domestic colleges and universities present situation, the university is divided into three school types. One is the researching university, two teaching and research university and heavy, 
three is the teaching oriented university. Undoubtedly, the private university belong the third type. It is decided not only by the students the cultural foundation and the ability of running, what is more decided by Chinese social and educational development needs. On Jilin province institutions of higher learning situation, most of the colleges in teaching contents, rich theory but poor practice; In the teaching link, attention to the theory and light practice; In talent evaluation, no more practical status and weight. It has seriously hindered the growth of high-quality talent. It is difficult to meet the needs of many employers need lots of new high-quality technical personnel needs. From the contradiction of education current status with needs of the community, can clearly see, set up the new concept of talent, must take on train the new application type talents as the primary development task of private university. This is the reality, but al is demand of own special advantages and sustainable development.

In the guidance of people oriented concept, the Changchun Institute of architecture rely firmly on the double division type of teachers, take on the practice teaching base group as the link, re enactment the talent training scheme of "to practice base group as the core, theory combines practice", to improve practical ability training system, to perfect the system of teaching mode. Adhere to running school with enterprises and the introduction of talent, to teach the construction technology to the students. We create "a platform supporting, shunt, four directions of various jobs training "personnel training mode, teach students in accordance with their aptitude, "Teach a man to fish", remarkable results have been achieved in training application technology talents.

\section{Establish Coordination Idea Take the Subject Fusion Deep as a Primary Strategy for Private University Development}

Scientific Outlook on Development emphasizes the balanced, coordinated development. Take on scientific outlook of development to guide private university construction, we must balance training with discipline construction, harmonious relationship between each discipline construction, course construction, to promote the deep combination of subject construction.

The creation of the teaching practice base group, provide the real engineering situation for students and teachers, optimization of the practical teaching system of the college to cultivate application technology and innovative talents. Students can realize the full process of zero distance further practice bases, complete theoretical study, practice and graduation design process. At the same time the study of the theory knowledge, to see want to see their real or model, to do their own interested experiment. Both teachers and professional basic course teachers, whether in the class or outside of class, can lead their students to the practice teaching base or laboratory, can introduce the nature, tasks, characteristics and difficulties of this course for students. Put the theory into practice, stimulate students' interest in learning, and inspire students' strong power to love special learning. So the target to training the application technology style talents.

Professional integration aspects, it is mainly reflected in the three point of growth to continue to develop: One is the professional course and the teaching practice base cluster fusion; two is the integration of professional foundation courses and professional courses; three is the integration of the teaching process and information technology. They are the main measures to cultivate applied personnel, improve the ability of running private university.

There are plans to implement production, teaching, scientific research combined in our institute. Especially the curtain wall engineering, all of the "three plus one" teaching mode, three years in school learning, learning at the production site for a year and complete the graduation design. Now the graduates in short supply.

At present, College of civil engineering in this respect has taken a welcome step: Many courses through deepening the teaching practice bases for teaching reform; The teaching model was summarized that combined with knowledge of the situation with practice teaching base group, the dual qualification teachers and information technology; The five rings teaching method was popularized that contain the central content of " situation creation, inspiration into the of science, to explore the rule, actual application, systematic induce". 
Since 2009 because of teaching reform to obtain the provincial level outstanding teaching achievement first prize 1, three prize 2 items. The simulation of construction platform we produced is extended to application in 8 the same university in China, widely acclaimed by the university.

\section{Conclusion}

Practice has proved, learning and practicing the Scientific Outlook on development, set up new non-government college as the primary goal of development, take on the cultivation of application technology talents as the primary task for private university development, people oriented, creation the practice teaching base group, there are plans to implement production, teaching, scientific research combined in our institute, enhance the core competence of running school, promoting the training application technology style talents.

\section{Reference}

[1]The Research of construction and application of practice teaching base group of civil engineering of independent institute, Yuan Qin Zhao, Jilin Education Science, 2008.5.

[2]The theory and practice of teaching mode innovation, Zuo Yang Ed, Jilin people's publishing press, 2002.5.

[3]The New Theory of teaching art, Hong Feng Liu Ed. Military Yiwen Press, 1995.12.

[4]Theoretical Mechanics, Yuan Qin Zhao Ed. Wuhan University Press, In May 2014. 